\title{
The New Aid Paradigm: A Case of Policy Incoherence
}

\author{
Geske Dijkstra \\ Program of Public Administration \\ Erasmus University Rotterdam, The Netherlands \\ PO Box 1738, 3000 DR Rotterdam, The Netherlands \\ dijkstra@fsw.eur.nl \\ Policy and Operations Evaluation Department (IOB) \\ of the Ministry of Foreign Affairs in The Netherlands
}

Published 24 June 2015

\begin{abstract}
From around 2000 onwards, donors and recipient governments embarked upon a new aid paradigm. The most important elements include increased selectivity in the aid allocation, more ownership of recipient countries based on nationally elaborated Poverty Reduction Strategy Papers (PRSPs), and more donor alignment and harmonization via programme-based approaches such as budget support. The paper assesses the theoretical merits of this new paradigm, identifying some contradictions and limitations, and then examines its implementation over the past decade and its results. The empirical literature largely confirms the earlier identified weaknesses and limitations. The paper concludes with some suggestions for improving aid practices.
\end{abstract}

Keywords: Aid effectiveness; Paris Declaration; selectivity; PRSP; budget support.

JEL Classification: O29

\section{Introduction}

At the end of the 1990s, there was widespread disappointment with aid and with what aid had achieved. Poverty was still rampant, and growth rates in many poor countries were still low, especially in sub-Saharan Africa. The lack of coherence with other policies of the rich countries, in particular trade, migration and security policies and the negative effects of the war on drugs are important factors in explaining the possible lower aid effectiveness. This paper, however, focuses on the lack of coherence within aid policies, and examines in particular the new aid paradigm that was adopted around the year 2000.

The disappointment about what aid had achieved led to several new initiatives at the turn of the millennium. There was broad consensus that aid levels should increase, and that aid should be more focused on poverty reduction. The international community adopted the Millennium Development Goals (MDGs) in order to focus development efforts on achieving concrete results. Several summits confirmed commitments to 
increase the level of aid, for example the 2002 Monterrey Conference and the 2005 Gleneagles G8 summit. In 1999, the initiative for the Heavily Indebted Poor countries (HIPC) was expanded, making larger amounts of debt relief accessible to more countries.

At the same time, however, it was recognized that fundamental changes had to be made in the way aid was provided. There were basically two criticisms to existing aid practices. One was directed against the structural adjustment programs of the 1980s and 1990s and their conditionality. These programs were blamed to have caused a worsening of social indicators, while there were also doubts about the effects of these programs on economic growth. In addition, the conditionality was often not effective in the sense that the agreed reforms were not implemented. The second critique on aid practices concerned project aid, which was still the dominant aid modality. The proliferation of projects and of donors, all with their own implementation units and their own procurement, accounting and reporting requirements had not only put an enormous burden on recipient countries but had also undermined local systems for planning and implementation.

These criticisms gave rise to a "new aid paradigm" that was expected to raise aid effectiveness. In response to the lack of effectiveness of policy conditionality, donors began to stress the need for selectivity in the aid allocation, only providing aid to countries with (proven) good policies and good governance. This selectivity would allow for another key element of the new aid paradigm, namely national ownership of recipient countries over their development strategies and over the aid process. Countries that wished to qualify for the enhanced HIPC initiative and also more generally for the International Monetary Fund (IMF) and World Bank facilities for Low Income Countries had to elaborate a Poverty Reduction Strategy Paper (PRSP). The strategies should be broadly owned, comprehensive, long-term and results oriented, and should form the basis for partnership with donors. It was expected that once these PRSPs existed, it was no longer necessary for donors to design aid projects. This move from project aid to program aid, and in particular budget support, is the third element of the new aid paradigm. It was expected to address the problems of project aid: The high transaction costs and the weakening of domestic systems. It would also foster government leadership over the aid process.

Many of these principles of the new aid paradigm were formalized during a high level meeting of more than 100 donors and recipient countries in Paris in 2005. This "Paris Declaration on Aid Effectiveness" included the following five principles (High Level Forum, 2005):

- Ownership: Partner countries exercise effective leadership over their development policies and strategies and coordinate development actions.

- Alignment: Donors base their overall support on partner countries' national development strategies, institutions and procedures.

- Harmonization: Donors' actions are more harmonized, transparent and collectively effective. 
- Managing for results: Managing resources and improving decision-making for results.

- Mutual accountability: Donors and partners are accountable for development results.

These principles are in line with, and build on the principles of the PRSP approach. The Paris Declaration sees broadly-owned national and sector development strategies, translated into results oriented plans, as the basis for achieving national ownership and leadership of the aid process, and for improving donor alignment and harmonization. The Paris Declaration stipulates that by $2010,66 \%$ of all aid would have to be given in the context of "program-based approaches", meaning that there is leadership by the host country, a single comprehensive program and budget framework, harmonization of donor procedures, and efforts to increase the use of local systems (High Level Forum, 2005). ${ }^{1}$ Budget support is considered the most advanced aid modality within such approaches.

It was expected that applying these principles, in combination with more aid, would help achieving poverty reduction and more in particular the MDGs. A decade later it is clear that progress towards the MDGs is mixed. Especially sub-Saharan Africa lags behind. The question is whether and to what extent this can be blamed to aid practices. This paper assesses to what extent the different elements of the new aid paradigm have been implemented in the past decade, and what the results have been. But before doing so, it is important to examine whether this new aid paradigm was the right answer to the observed problems of aid effectiveness.

In Sec. 2, the paper begins by scrutinizing the contents of the new aid paradigm itself, showing that it contains errors of commission and of omission: It has several internal contradictions, and it left some important problems unaddressed. Sections 3-5 analyze the extent of implementation and the results of the three main elements of the new aid approach, viz. selectivity, the use of PRSPs as means to promote ownership and to focus on poverty reduction, and the Paris Declaration and the move to budget support as a means to foster ownership, harmonization and alignment. Section 6 concludes the paper and provides some recommendations.

\section{The New Aid Approach: Expectations and Limitations}

\subsection{Origins}

In 1998, the World Bank published a study that would become very influential (World Bank, 1998). It had two main conclusions. The first was that aid is more effective in a good policy environment, and the second that policy conditions of donors are not very effective. Countries only implement what they intend to do anyway, and political economy factors determine what is eventually implemented. This second conclusion

\footnotetext{
${ }^{1}$ Aid within program based approaches may include project as well as program aid. Program aid is non-earmarked aid and budget support is one of its modalities.
} 
was in line with much other contemporary research, and led to the conviction that policies should be "owned" by recipient countries. The first, however, was severely criticized as being on shaky econometric grounds (for example, see Hansen and Tarp, 2000 and Lensink and White, 1999). Yet, it led many donors to adopt the principle of selectivity in their aid allocation, providing aid only to countries with good policies and good governance. In addition, aid's effectiveness for poverty reduction was expected to increase by providing aid only to the poorest countries.

It was hoped that more selectivity "ex post", on proven levels of policies and governance, would also reduce the need for conditionality "ex ante" and so bring about more ownership. Broad-based ownership of recipient countries of policies and of aid processes was considered important because it would secure commitment and thereby foster policy implementation and aid effectiveness.

When the debt campaigners were successful in achieving more extensive debt relief for the poorest countries, a broad coalition in the international community was in favor of securing that the monies freed from debt payments would be used for poverty reduction and for achieving the MDGs. Combined with the urge for recipient country ownership, this led to the idea that countries would have to elaborate a PRSP with broad participation of civil society in order to access the debt relief. The PRSP would serve both as a guarantee that country policies would be focused on poverty reduction, and as means to secure - broad - national ownership over policies.

The partnership principle of the PRSP approach implied that, once a broad-based national plan was put in place, donors would support this plan and this would reduce the need to design and implement separate projects. This would also address some other problems of the aid architecture (see Fig. 1), namely the high transaction costs of project aid, especially for recipient countries, and the fact that all the different implementation units and aid monitoring systems undermined national systems of planning, implementation and monitoring. Several high level meetings (Rome 2003, Paris 2005 and Accra 2008) confirmed the commitments of both donors and recipient

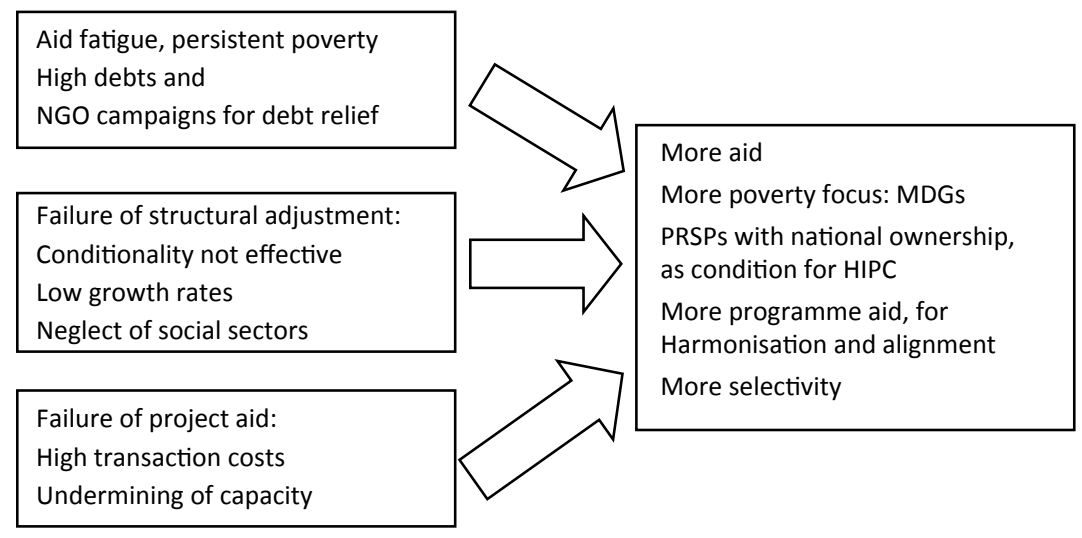

Figure 1. Change in international aid architecture around 2000.

Source: Own elaboration of the author. 
countries to adhere to some principles of aid effectiveness. These commitments were most clearly stated in the Paris Declaration: ownership, alignment, harmonization, a results orientation and mutual accountability. The move from project aid to program aid (budget support) was expected to help achieving these principles.

In sum, the new aid paradigm consists of more selectivity in the aid allocation, the promoting of PRSPs as basis for ownership of the aid process, and the application of the principles of the Paris Declaration with budget support as the champion aid modality. However, the new aid approach suffers from internal contradictions and leaves a number of problems unaddressed. These errors of commission and omission will now be discussed.

\subsection{Contradictions}

The principles of the PRSP and the Paris Declaration represent the dominant perspective on the problems with aid and the need for a new paradigm, but there is also another "narrative" behind the new aid paradigm — one that reflects a more negative view of the aid recipient (Renard, 2005). From this second perspective, aid failed because of inadequate policies and governance in the recipient countries. Following this view, conditionality did not work because donors were too lenient with governments. This leads to the conclusion that donors should keep and even strengthen policy conditionality. Both perspectives on conditionality and ownership circulate in the donor community and sometimes even within one donor agency. This is what Rogerson (2005) calls the "schizophrenia" of the aid industry: conditionality is still important in aid practices, yet the Paris Declaration is completely silent about it (Rogerson, 2005).

The ownership principle is perhaps the most important element of the new aid paradigm, but also the most confusing one. Real ownership implies that countries have control over their own policies; that they are in the driver seat (Whitfield, 2009a). It means respecting that countries should decide on their own policy and institutional experiments and make their own mistakes (Khan, 2012). Donors, however, often seem to define ownership as commitment to the preferred policies of the donors. This view is also present among academics. Martens (2008), for example, writes that there can only be full ownership if the preferences of recipient countries are aligned with donor preferences. In a similar vein, Booth speaks of "ownership of development efforts", arguing that this is not always present in low income countries and that it should be fostered by sensible aid efforts (Booth, 2011a). But this is not real ownership. It can also be questioned whether "ex post" selectivity indeed means less conditionality and more ownership. Countries badly in need of aid will try to improve on the selection criteria for the aid allocation. This implies that conditionality continues and perhaps even intensifies.

Applying the principles of the Paris Declaration is assumed to enhance aid effectiveness, but it is not recognized that effectiveness is a value laden concept. Ideas on 
what the desired effects are may differ. Similarly, the "results orientation" of the Paris Declaration and of the PRSP approach assume that donors and recipients have the same objective function and wish to see the same results. However, the donor's constituencies are not homogeneous, and therefore one donor has multiple objectives (Martens, 2008; Svensson, 2008). A large number of donors have even more different objectives. The desire to show aid results to (different) domestic constituencies therefore also hampers donor harmonization (Knack and Rahman, 2004).

Assuming all differences in preferences between donors and recipients away, most of the principles of the Paris Declaration deal with aid efficiency: Alignment to national priorities and using national systems, and lowering transaction costs. However, transaction costs exist precisely because donors want to secure spending and implementation in line with their preferences (Martens, 2008). In this sense, there is a tradeoff between effectiveness and efficiency.

Some of these contradictions were already evident in some aspects of the design of the new aid approach. Although broad-based and national ownership of PRSPs was considered important, donors at the same time wanted PRSPs to further the achievement of the MDGs. MDGs have been criticized for being not sufficiently countryspecific. In this respect, countries were not completely free in setting their own priorities (Renard, 2005). Ownership of PRSPs was further undermined by the fact that they had to be "endorsed", in fact, approved, by the World Bank and the IMF, so this reduced the possibility of real ownership, or ownership in the sense of control over policies by recipient governments.

Another tension of the new approach was related to the requirement of broad-based ownership of PRSPs, based on participation of civil society. Some considered this to be process conditionality, which would be better than content conditionality. ${ }^{2}$ In fact, if - elected - governments are not in favor of participation, "broad-based ownership" is a contradiction in terms. It was also not very clear what "participation" implied; whether it would just be consultation without any consequences, or whether civil society needed to have influence on the strategies. In the latter case, questions could be raised on the representativeness of civil society and on the relation of these processes with elected parliaments (Molenaers and Renard, 2009).

PRSPs were supposed to be comprehensive long-term strategies to reduce poverty, and at the same time to be sufficiently operational to guide aid efforts and to translate in annual government budgets. In line with this, one of the indicators for ownership in the Paris Declaration is that partner countries have "operational strategies". However, translating a long-term overall vision into concrete activities and budgets is almost impossible. Establishing such a link between comprehensive plans and annual budgets has already been tried several times in history, for example, in the Planning Programming and Budgeting System in the United States in the 1960s (Gunsteren, 1976).

\footnotetext{
${ }^{2}$ They implicitly assumed that content conditionality was absent — which was not the case given the need for endorsement of the strategies.
} 
It has never succeeded. Furthermore, creating technocratic long-term plans for the whole economy and society is apolitical and unrealistic. The attempt at rational planning assumes that there is no politics involved in decisions on policy priorities, and that implementation is automatic once the plan has been approved. In reality, policies are determined in political processes involving short-term negotiations and compromises between different viewpoints. Implementation processes are therefore never automatic; they are influenced by political motivations and incentives and by changed circumstances. Central planning has proved to be inefficient and has long been abandoned in OECD countries; yet, it is still very popular among aid experts.

\subsection{Errors of omission}

There are two other fundamental problems with the new aid paradigm. First, looking at the problems of the international aid architecture and their responses (Fig. 1), one problem conspicuously remains unaddressed. That is the low economic growth rates resulting from structural adjustment programs. Although particular conditions were not always carried out fully and immediately, most aid dependent countries began to adopt gradually the policies as prescribed by IMF and World Bank. They reduced government expenditure, liberalized domestic markets and foreign trade, privatized stateowned enterprises, first in production but then also in public utilities, and some also liberalized their capital accounts. But by the end of the 1980s, structural adjustment policies came under increasing critique. They did not have sufficient attention for social policies so that social indicators deteriorated, ${ }^{3}$ and they were not conducive for growth.

There is increasing evidence that that IMF programs have not led to economic growth, also if controlled for the "selection bias"4 (Barro and Lee, 2005; Easterly, 2005; Przeworski and Vreeland, 2000; Vreeland, 2007). The World Bank also recognized that its growth policies have not always been successful (World Bank, 2005), although one econometric study reports somewhat better results for the Word Bank than for the IMF (Butkiewicz and Yanikkaya, 2005).

The critique on the all-out liberalization and privatization of economies also came from economists who studied the history of development and more in particular the Asian experience (Amsden, 1989, 2007; Chang, 2002, 2007). The currently developed countries have all used a lot more state intervention than developing countries are now allowed to practice. The new aid paradigm with its emphasis on MDGs and poverty reduction detracted the attention from these fundamental criticisms on the growth enhancing nature of standard policy prescriptions.

A second unaddressed problem is related to the limits to the absorption capacity for aid. The new aid paradigm stresses that the lack of donor coordination and lack of

\footnotetext{
${ }^{3}$ At an early stage already recognized by Cornia et al. (1987).

${ }^{4}$ The fact that IMF programs are implemented in countries with low growth.
} 
alignment with country systems increases transaction costs and undermines local capacity. There is ample evidence that the lack of donor coordination does bring about high costs for recipient countries (Acharya et al., 2006; Knack and Rahman, 2004). Knack and Rahman (2004) also examined the effect of donor fragmentation ${ }^{5}$ on the quality of governance in a sample of 96 countries, and found that it is negative and significant. In sub-Saharan countries, donor fragmentation proved to weaken the quality of governance even more. Yet, even full donor harmonization is no guarantee for aid effectiveness, as the Dutch involvement in Surinam has shown. Even with full harmonization and alignment, a large volume of aid is still likely to undermine national capacities.

Studies on aid effectiveness often start with the observed "micro-macro paradox": while most evaluations of aid projects reveal positive results, the outcomes at the macro (country) level are less convincing (Mosley, 1986). Econometric studies on aid effectiveness show highly varying results (see Quibria, 2014 for a recent review), but there appears to be some consensus that aid has a small positive effect on growth (Radelet and Levine, 2008; Mekasha and Tarp, 2013), especially in the long run (Arndt et al., 2014). Yet, there is an increasing number of fairly robust studies showing diminishing returns (Hansen and Tarp, 2001; Rajan and Subramanian, 2005). The pleas for "scaling up" (Sachs, 2005) ignore these effects.

The literature suggests that the negative effects of large volumes of aid may be due to economic, or to institutional and political factors. On the economic side, aid may increase the real exchange rate and produce harmful effects on the country's exports, although economists disagree on the extent to which this "Dutch disease" occurs (Serieux, 2007; Fielding and Gibson, 2013). Yet, in order to avoid Dutch disease effects, some African countries decided to not fully absorb foreign aid (Booth, 2011b; Killick and Foster, 2007). Another negative economic effect of aid is that it may reduce the efforts to raise taxes, the so-called "fiscal response" (White, 1998).

However, the institutional and political effects are potentially even more harmful. Aid may reduce domestic efforts to foster development (also see Svensson, 2008). The aid system has in-built perverse incentives. At a macro level, the country can only receive aid if its income per capita remains low. But similar effects are likely to happen at lower levels. If the auditor general office spent the money meant for doing audits by raising salaries, donors respond by giving more aid. ${ }^{6}$ In numerous cases, perverse behavior of recipients is rewarded, not punished. Perverse effects are also visible in the labor market. Donor agencies distract staff from the government and from the private sector by offering higher salaries and a more rewarding working environment. This weakens the state sector and reduces incentives for building up a vibrant private sector (Brautigam and Knack, 2004; Knack and Rahman, 2004; Wuyts, 1996).

\footnotetext{
${ }^{5}$ Measured as the reverse of concentration: $(1-$ Herfindahl index $)$.

${ }^{6}$ This occurred in Nicaragua, for example.
} 
In addition, attention has been raised for the possibility that large amounts of aid to governments reduce domestic accountability. Government officers dedicate most of their time and effort to render accounts to the donors. As long as a large part of government income "falls from heaven", parliaments and the population at large do not have incentives to monitor how governments spend this money (Killick and Foster, 2007; Moss et al., 2006; Moyo, 2009). It is only when taxes are raised, that populations demand voice. These issues receive very little attention in the new aid paradigm - with one exception. One of the hoped-for secondary effects of budget support is precisely to increase domestic accountability. The donors require reports on government policies and government expenditure and they hope that this more transparent reporting will be used by civil society and parliaments in order to hold their governments to account. It remains to be seen whether this is the case.

\section{Selectivity}

This section aims to answer the question whether donors have become more selective in their aid allocation, what the selection criteria have been, and what the likely results of the applied selectivity are. In particular, it is important to examine whether the selection criteria can be expected to have been helpful for growth.

For the situation before 2000, several studies concluded that high debts, and especially high multilateral debts, were an important factor determining the aid level (Birdsall et al., 2003; Cordella et al., 2005; Hernández and Katada, 1996; Marchesi and Missale, 2004). Both the IMF and World Bank lent into arrears, thereby allowing countries to repay earlier debts. Once countries had an IMF agreement, other donors were also more likely to provide aid (Dijkstra, 2008). One study even concluded that there was adverse selection: countries with poor policies, as measured by the Country Policy and Institutional Assessment (CPIA) of the World Bank, were given more aid until 1999 (Birdsall et al., 2003).

Several studies have examined whether aid has become more selective after around 1999. They use different methods, and often also examine different criteria, including different indicators for poverty, good policies and good governance. Dollar and Levin (2006) look at the influence of two measures for good governance, the rule of law (ICRG) and democracy (Freedom House Index), as well as of poverty (GDP per capita) and several control variables. They compare the period 2000-2003 with earlier periods from 1984 onwards. All donors proved to provide more aid to the poorer countries and total aid was selective on democracy but not on rule of law. There was no evidence of increased selectivity, except for the multilateral donors but this already started in 1995-1999 (Dollar and Levin, 2006).

Nunnenkamp and Thiele (2006) showed that the poverty allocation of aid from all DAC donors deteriorated in the more recent period (1999-2002) as compared to the 1980s. In theory, this could be due to a larger flow to countries with good governance. However, they also found that aid did not prioritize countries with better scores on the 
World Bank's Country Policy and Institutional Assessment (CPIA). Multilateral donors as group did not perform better than the average donor. They also found that donors did not give more aid to countries of which the governance score improved between 1996 and 2002 . $^{7}$

Hout (2007) examines the aid allocation of three donors that have officially announced that they would become more selective on good governance: The World Bank, in particular IDA (for the period 1998-2006), The Netherlands (for the same period), and the USA for its Millennium Challenge Account (MCA, in operation since 2004). The World Bank and the Netherlands give a heavy weight to economic policies in their allocation decisions, while political criteria have a heavier weight in the MCA. He uses the six governance indicators composed by Kaufmann et al. (2004) of the World Bank Institute, as well as a composite variable based on principal components analysis. This analysis shows that governance, especially the composite variable, is an important determinant of aid in all three cases. However, the significance disappears for the second period (2002-2006) in The Netherlands, in line with qualitative evidence of reduced selectivity in that country (Hout, 2007).

Another study examined the selectivity of aid (and debt relief) ${ }^{8}$ among a group of 62 low-income countries from 1989 to 2003 (Depetris Chauvin and Kraay, 2006). While they find that in the first five-year period (1989-1993) countries with worse policies (measured by the CPIA) received more aid, this was reversed in the last (1999-2003). This seems to indicate that selectivity in the aid allocation has improved since 1999. Yet, a recent study of donor performance reveals that the share of aid going to low income countries does not show any consistent trend between 1990 and 2008 (Easterly and Williamson, 2011). The share of aid going to corrupt countries proves to have increased between 1995 and 2002 and has fluctuated at a higher level since then. The share of aid going to democratic countries remained constant as well, while more aid flowed to in-between countries than to autocratic countries. However, the apparent changes in country allocation in both cases proved mainly due to changes within recipient countries, and not to increased donor selectivity (Easterly and Williamson, 2011, pp. 1941-1942).

The evidence on selectivity is not very conclusive, but what is clear is that the World Bank-IDA allocation has become more selective on the CPIA and possibly also on governance. For the World Bank this is not surprising, as it uses the CPIA in order to allocate its loans and grants since 1998, along with a measure of poverty and of the size of the population. The CPIA contains four clusters, and together they represent both "good policies" and "good governance". Other criteria also play a role, such as poverty (income per capita), population size, and past portfolio performance. But the weight of the CPIA is 16 times the weight of poverty and twice the weight of the

\footnotetext{
${ }^{7}$ Using the control of corruption and rule of law scores among the Kaufmann et al. governance indicators of the World Bank Institute (Kaufmann et al., 2004).

${ }^{8}$ I exclude the results for debt relief; a stock measure of debt forgiveness was used in this study, which does not say anything on the flow effects of debt relief (Dijkstra, 2008).
} 
population (Van Waeyenberghe, 2009). The governance cluster in the CPIA has a double weight as compared to the other clusters, because it is also used as a separate governance factor. Since 2005, both the criteria and the country scores (at least for IDA countries) have become public. This is beneficial for the transparency of the World Bank but at the same time it gives the World Bank's standards and criteria more leverage: It is likely that aid dependent countries will attempt to improve their scores in order to receive a higher share of the IDA allocation.

\subsection{Selectivity on what?}

The question then is what are the good policies and good governance criteria that the World Bank uses? In the policy area, it was expected that the renewed attention for poverty of the new aid paradigm would give a higher priority to social policies. In addition, it has been claimed that there is now a "Post Washington consensus" that would eliminate the strongest pro-market biases of the earlier structural adjustment policies. With respect to governance, the question is whether the governance criteria included in the CPIA indeed promote economic growth.

The CPIA contains clusters on economic management, structural policies, social inclusion, and a governance cluster called "public sector management and institutions". The first two clusters are still reflecting the Washington Consensus, rewarding low inflation, a budget surplus, free trade and free capital flows, flexible goods, labor and land markets, market-determined interest rates and absence of directed credit, equal treatment of foreign investors, protection of shareholder rights, capital account convertibility and open public sector procurement. This precludes strategic interventions that have proven to be so important in the now developed countries (Amsden, 2007; Chang, 2002).

The 2004 CPIA, however, shows changes in the structural policies cluster, in particular in the questionnaire (the "narrative guidelines") that is used by the country experts having to do the scoring. Free flows of capital and equal treatment of foreign investors are no longer mentioned, and directed credit is no longer banned. However, Van Waeyenberghe (2009) also examined the "guideposts" to the scoring exercise, which have become more extensive after the changes in the "narrative guidelines". These "guideposts" refer extensively to World Bank diagnostic reports such as Diagnostic Trade Integration Studies, Investment Climate Assessments, Administrative Barrier Reports, financial sector assessments. These reports and assessments fully reflect the biases of the "old" Washington Consensus. The contents of these reports therefore eliminate the changes introduced in the narrative guidelines (Van Waeyenberghe, 2009).

The cluster "Policies for social inclusion" includes gender equality, equality of public resource used, building human resources, social protection and labor, and policies and institutions for environmental sustainability. Some of these policies are constrained by the macro-economic policies of the first cluster or they are in 
contradiction with structural policies that prescribe, for example, an easy hiring and firing of labor (Van Waeyenberghe, 2009, p. 800).

The cluster on governance contains property rights and rule-based governance, quality of budgetary and financial management, efficiency of revenue mobilization, quality of public administration, and transparency, accountability and corruption in the public sector. The big question is whether these policies and institutions are necessary for economic development and for aid effectiveness. Several authors have shown that the now developed countries started to grow with a level of institutional development that was much lower than that of the current developing countries (Chang, 2002; Goldsmith, 2007). This allows for the possibility that these institutions are induced by a higher level of development. The evidence for a causal link from a high score on the Kaufmann indicators to economic growth, is weak (Khan, 2006, 2012; Kurtz and Schrank, 2007).

Khan distinguishes between market-enhancing governance and growth enhancing governance (Khan, 2006). The current orthodoxy as reflected in the CPIA ${ }^{9}$ holds that market-enhancing governance is necessary for growth, but that need not be the case. In Khan's view, the problems of catching up require governance that addresses the market failures that maintain low productivity in developing countries. This involves a lot more strategic government intervention than the market enhancing governance allows for. Other authors also criticize the rigid way in which the orthodox good governance criteria are defined. The best institutions for each country are context specific and path dependent (Quibria, 2014, p. 81). There are many ways in which property rights can be protected, for example, (Andrews, 2008). It is also possible that in an imperfect environment, the application of international best practices for one institution leads to suboptimal or even worse outcomes for economic growth, for example, when setting up or reforming a formal institution weakens or destroys earlier informal institutions (Rodrik, 2008). Similarly, it may be dangerous or too costly to attempt to implement many reforms at the same time (Grindle, 2004).

In sum, using the CPIA as selection criterion is not likely to promote growth. This means that the selection criteria for IDA loans and grants are still dominated by criteria that, if applied, do not foster growth in these aid dependent countries. Given that there is increasing harmonization among donors on the selection criteria, this is a dangerous development.

\section{Poverty Reduction Strategy Papers}

The elaboration of a PRSP was a requirement for access to the HIPC Initiative. It also became condition for the IMF facility for low income countries (PRGF) and for the IDA (World Bank) development policy loans for low income countries, the Poverty Reduction Strategy Credits (PRSCs). Furthermore, the elaboration of a national

\footnotetext{
${ }^{9}$ Applies to the Kaufmann indicators as well.
} 
poverty reduction or development plan that would form the basis for development aid has become a condition for most donors.

Since 2000, 60 countries have elaborated a full PRSP, including many low income countries and also several middle income countries. Several countries produced a second and some even a third strategy. ${ }^{10}$ Most countries with a PRSP have presented PRSP Progress Reports as well, although no country managed to do this annually as was the original idea. These 60 countries presented in total 106 PRSPs and 98 Progress Reports until February 2011. In this respect, the PRSP has been implemented widely.

In the remainder of this section, I briefly summarize the evidence to date on the PRS process, focussing in particular on the degree of ownership of the strategies and on the extent to which they have contributed to the implementation of poverty reduction policies.

Although countries usually did not take the initiative for writing PRSPs, PRSPs may still be nationally owned. The degree of ownership of the strategies depends on the size of the circle of local actors that have a "perception of possession" of the strategy (Stewart and Wang, 2003). This perception may be limited to the group of technocrats who designed the strategy, may include the top political leadership or key political officers such as the Vice-President or the Minister of Finance. Ownership is broader if other ministers are involved, and even more if this ownership is extended to all public sector officers. Finally, ownership is really broad-based if it extends beyond the executive, including a majority in parliament, opposition parties, civil society organizations and the public at large. ${ }^{11}$

Most studies of the original PRSPs that were elaborated in order to qualify for the HIPC initiative (the "first generation" of PRSPs) conclude that ownership was fairly limited. It usually included the group of technocrats writing the strategy plus some key political leaders - those who were most interested in accessing the debt relief. Ownership among other policymakers such as the line ministries was limited (Booth, 2005; Dijkstra, 2005; Driscoll and Evans, 2005; Holtom, 2007; Whitfield, 2005; Woll, 2008). Parliaments were seldom involved and often were hardly aware of the existence of PRSPs. The fact that the strategy had to be approved by World Bank and IMF limited the possibilities for ownership and thus also for ownership among the wider society (IEO, 2004; OED, 2004).

In Latin American HIPC countries, new governments were elected soon after the first PRSPs had been approved (Dijkstra, 2005). These new governments rejected the "old" strategy, but as Honduras and Nicaragua had not reached the Completion Point for the HIPC initiative yet, governments of these countries continued to write Progress Reports and began to work on new or revised plans. Only in Nicaragua this led to an approved second PRSP which was strongly owned by the executive government of the

\footnotetext{
${ }^{10}$ Source for these data on approved PRSPs and Progress Reports: www.worldbank.org, accessed 6 February 2011.

11 This is loosely based on the classification in Booth (2003).
} 
day, but it was soon to be rejected by yet another new elected government. There is not much evidence on ownership of second or third strategies for sub-Saharan Africa. In Ghana, donors interfered much less than before in the elaboration of these strategies (Woll, 2008). They were not so much interested in the contents of the strategies, but much more in the show (the PRS process) going on. In Uganda, high-level political ownership of the 2005 strategy was lower than in the two previous poverty reduction strategies (1997 and 2001). This is explained by the fact that the two earlier strategies had a higher budget and could include high-profile and politically attractive measures, such as free education and health care (Canagarajah and Diesen, 2006).

With respect to ownership among the larger population, most authors concur that the organized participation processes were, at best, a form of consultation (Gould, 2005; Lazarus, 2008; Molenaers and Renard, 2003; Stewart and Wang, 2003; Vos et al., 2003). To the extent that civil society groups were invited to discussions at the national or regional level, the agenda was usually determined by the government. Discussions hardly ever extended to macro-economic policies or structural reforms. Useful participation was also limited because invitations and relevant documents did not arrive in time, or civil society constrained itself as it had an interest in receiving debt relief (IOB, 2003).

In Bolivia extensive consultations were held, but there was a huge gap between the outcomes of these discussions and the later strategy, which was written by a group of technocrats with inputs from line ministry officers and donors (Komives et al., 2003). This points to the difficulty of integrating many and widely diverging detailed demands in a national strategy - both practically, and politically. This gap between consultations and plan content also held for the consultations held for some second generation PRSPs. In Uganda and Tanzania, for example, extensive grass roots consultation processes were held, financed by donors. This led to thousands of pages of reports and that was far too much to be used in the actual strategies (Canagarajah and Diesen, 2006; Hartog, 2005). Actual influence was therefore limited.

\subsection{Implementation}

In order to assess the influence of the strategies for actual poverty reduction policies, it is important to examine first the contents of the strategies and then the extent of their implementation. The contents of the strategies proved to reflect the then dominant international poverty agenda: macro-economic stability, market liberalization, attention for good governance, and a focus on social sectors and social protection mechanisms (Craig and Porter, 2003; Stewart and Wang, 2003). In so far as growth policies were included, they stressed macro-economic stabilization with limited flexibility for addressing shocks or for expanding social expenditure (Gottschalk, 2005). This is another proof of limited country ownership, but also of continued dominance of the Washington Consensus in so far as growth policies were concerned. Donors usually complained about the heavy focus on social policies in the first PRSPs and on the lack 
of attention for policies to increase growth (apart from maintaining macroeconomic stability), and this was also concluded in evaluations (IEO, 2004; OED, 2004). However, it was usually donor influence that led to this focusing on social policies and neglect of economic growth in the first place.

The attention for growth was usually better in second or third strategies, again showing that countries listened well to their financiers. But apart from a somewhat higher priority for physical infrastructure, growth policies did not become very concrete (Canagarajah and Diesen, 2006; Woll, 2008). Given the constraints of the still dominant Washington consensus, it was of course difficult for countries to design specific growth promoting policies. In Nicaragua, the second PRSP, owned by the executive, did promote growth but neglected equity (Guimarães and Avendaño, 2007).

Most PRSPs were hardly implemented. Implementation was limited to policies that were already under way before the PRSP started, to donor-financed projects and to some political measures with high-level support, such as free education ("Universal Primary Education" in Uganda). A first problem was that PRSPs suffered from a lack of priority setting and of operationalization and costing of policies. In several countries (for example, Ghana, Nicaragua) costing exercises were only available for projects that were to be financed by the donors. The 2006 OECD Survey on the implementation of the Paris Declaration shows that no country had achieved "good practice" in making operational strategies, and that only 5 out of 34 countries (17\%) had "largely developed toward good practice." (OECD, 2008, p. 17). Most national development strategies still lacked realistic costing of and prioritization of activities.

Another often mentioned problem is that there were only weak links between the PRSPs and the processes of formulation and approval of government budgets. These processes themselves were still weak. Donor attempts to reform public financial management, for example by introducing MTEFs, performance management and activity based costing are far too complicated and "drain available capacity". In practice, improvements were sometimes observed in budget formulation, but budget execution and accountability remained weak. ${ }^{12}$ Although several African countries developed Medium Term Expenditure Frameworks (MTEFs), these MTEFs are sometimes only existing on paper and do not provide real budget constraints, as in Mozambique (Cheru, 2006). Budgets are often just a "façade" (Rakner et al., 2004). In Ghana, there proved to be an almost $50 \%$ difference between budgeted expenditure and actual expenditure per ministry, on average (Lawson et al., 2007).

All in all, PRSPs largely remained a paper exercise. This was not only due to limited domestic ownership, but also to the practical impossibility to link technocratic, comprehensive, long-term plans with concrete day-to-day political decisions. It is also unrealistic to assume that a long-run consensus on how poverty must be dealt with can exist at all. Actual policies and actual spending have far more to do with complex

${ }^{12}$ Dorotinsly and Floyd (2004) cited in de Renzio (2006). 
political negotiations in a context of continuing neo-patrimonial relationships, than with PRSPs or approved budgets. Gould concludes on the basis of a study of PRSP processes in several countries that there are two "disjunctures": Between policy and politics, and between policy formulation and implementation (Gould, 2005). In my view, the two are related. While donors and some top technocratic officers are working on the formal documents (PRSP) and negotiate PRSCs and performance assessment matrices for budget support, the political process in which actual policies and spending are determined is an entirely different matter. Formal processes are more like a virtual reality that has little to do with actual policy making and spending decisions.

\section{The Paris Declaration and Moves to Budget Support}

Now we get to the crux of the new aid paradigm, the introduction of the five principles of the Paris Declaration: Ownership, not just of a PRSP or national strategy, but of actual policies and of the aid process, alignment with country priorities and systems, donor harmonization, managing for results and mutual accountability. To what extent are these principles applied? This section answers that question, and looks at the aid modality that is supposed to advance these principles most, namely budget support.

In view of the importance attached to the principles of the Paris Declaration, the OECD carried out a large survey among 34 aid receiving countries on the application of the principles in 2006 (OECD, 2008). In particular, the 12 targets of the Declaration were monitored. The results show that there has been some progress, but that is unlikely that the targets for 2010 will be met. This conclusion is in line with findings of other studies (Booth, 2005; Driscoll and Evans, 2005; Cheru, 2006; Dijkstra and Komives, 2011). It is interesting to analyze some of the targets examined in the survey and their outcomes in more detail.

For ownership and leadership of the aid process, the survey looked at whether countries had operational national development strategies, and whether governments had set up sector working groups in which donors and governments discuss and coordinate policies for a sector. The survey concludes that national strategies were not sufficiently operational, and that sector working groups were often established in health and education, but much less so in other sectors. However, it can seriously be questioned whether these two issues are valid indicators for ownership. Industrialized countries seldom have national, operational development strategies and yet they certainly own their policies. Furthermore, the existence of sector working groups in which donors are involved in sector policies was found to actually reduce ownership (Whitfield, 2009a).

With respect to alignment, between $38 \%$ and $98 \%$ of aid was reported to be on budget. Actual disbursements were often much larger than aid included in the budget. Countries with a MTEF found it impossible to get reliable predictions of donor disbursements in years $n+1$ or $n+2$. Only about $40 \%$ of on-budget aid used country public finance management and procurement systems, and parallel implementation 
units were still widespread. ${ }^{13}$ Another finding is that there proved to be hardly a link between the use of these systems and their quality. In the area of harmonization, the survey examines progress towards program-based approaches and towards joint missions (18\% of total) and joint analytical work (somewhat higher at $42 \%)$. For "managing for results", the survey examined the result orientation of performance assessment frameworks and finds that there is moderate progress towards best practices. For "mutual accountability" it was registered whether a mechanism is in place for mutual review of progress on the Paris Declaration principles, which was the case in $44 \%$ of countries. However, the indicators for "managing for results" and for "mutual accountability" only partially seem to cover the original ideas.

Measuring the extent to which there were program-based approaches proved to be a challenge. This is partly due to the vague way in which these approaches are defined, for example there should be "efforts to increase the use of local systems...". The survey attempted to count aid within program-based approaches but also registered the easier category of budget support, defined as non-earmarked aid. It is true that nonearmarked aid by definition is fully aligned, but it need not be fully harmonized. The Survey found that $43 \%$ of aid was delivered in program-based approaches, which is still far away from the target of $66 \%$ in 2010 . Within program-based approaches, budget support proved to be $20 \%$ of total aid, on average.

This number is in line with other studies. According to the most recent Annual Survey of Budget Support undertaken for the SPA (2007), the number of donors involved in joint general budget support agreements in Africa has increased between 2004 and 2007. All fourteen countries reviewed in this Survey received General Budget Support, and by 2007, 11 out of 14 have a formal joint Memorandum of Understanding for its provision. But the amount of GBS is still small relative to total aid to these countries: $21 \%$, on average. If we add sector budget support, ${ }^{14}$ the share of these two modalities becomes 24\% (SPA BSWG, 2008).

In three reviewed Latin American countries (Bolivia, Honduras and Nicaragua), a joint framework for budget support existed only for one year in Bolivia and for a longer period (2005-2009) in Nicaragua. The share of non-earmarked aid (including balance of payment support - especially important in Bolivia in 2003-2004) in total aid constituted only $15 \%$, on average in these three countries. This was much lower than the $22 \%$ share of freely spendable aid ("program aid", mainly balance of payments support) in total aid over the years 1995-2000 (Dijkstra and Komives, 2011). It can be expected that this also holds for many other countries receiving budget support. Despite the rhetoric of the new aid paradigm, the share of freely spendable aid in total aid may actually have decreased as compared to the 1990s, instead of increased.

While donors increasingly discuss and study the advancement of the Paris Declaration principles of harmonization and alignment, these efforts appear an uphill

\footnotetext{
13 The average recipient country had 54 of them (1832 implementation units divided by 34 countries).

${ }^{14}$ This is also non-earmarked aid, but with policy conditions for a specific sector.
} 
struggle in view of changing realities. In recent years, donor coordination became increasingly difficult due to the entrance of new donors and new programs. First, the number of donors increased due to new countries entering the European Union. Countries such as the Czech Republic and Hungary, in their desire to comply with EU guidelines, started to enter the donor scene. They may be willing to adhere to the Paris Declaration principles, but their entrance makes coordination more difficult. Second, several non OECD/DAC donors are becoming increasingly important, like China and Venezuela. These donors do not feel constrained by the Paris Declaration principles at all. They follow their own policies and conclude direct bilateral contracts with recipients.

Third, the drive towards increasing aid and increasing aid effectiveness has brought about new global aid initiatives, including the Global Alliance for Vaccines and Immunizations (GAVI), the Global Fund against Aids, Tuberculosis and Malaria (GFATM), and the President's (Bush) Emergency Plan For Aids Relief (PEPFAR). The Millennium Challenge Account (MCA) of the United States may also be classified in this group because it was aimed at increasing aid effectiveness by selecting countries with good governance only. These initiatives all have their own disbursement, implementation and monitoring procedures, implying that they bypass country systems for planning, implementation and monitoring. Each new concern of the international community (HIV/AIDS, governance, climate change) seems to bring about more donor proliferation. ${ }^{15}$

A preliminary evaluation of some of these initiatives (MCA, GFATM and GAVI) shows that they do well on the Paris Declaration principle results orientation, focusing on concrete objectives and applying performance-based disbursement. But they do less well on country ownership, alignment and harmonization (Radelet and Levine, 2008). In a country like Uganda the total aid from global health initiatives was US\$ 160 million over 3 years (2004/5-2006/7). This aid was completely off-budget and was mostly provided to the private sector. This hampers a proper health planning by the government (Nabyonga Orem et al., 2009).

\subsection{Budget support}

Donors that are in favor of providing budget support claim that they only start this modality if certain conditions are fulfilled in a recipient country. The country must have macro-economic stability, the government must be committed to poverty reduction, meet minimum standards with respect to government budgeting and accounting, and have good governance, implying also that it respects democratic principles and human rights. Countries seldom meet all these conditions. Most current donor darlings are weak democracies with limited checks and balances, high degrees

\footnotetext{
15 To date, there are already 18 different funds for climate change (ODI blog by Geoff Handley, accessed 26 February 2010, http://blogs.odi.org.uk/blogs/main/archive/2009/02/26/7085.aspx.
} 
of corruption and of clientelism (Chabal and Daloz, 1999; van de Walle, 2001). As donors were desperately willing to start budget support, this had two consequences.

First, they resorted in practice to relatively simple selection criteria. These usually included that the IMF agreement should be on track, as measure of macro-economic stability, and there should be an approved PRSP as indicator for commitment with poverty reduction. Governance criteria or real (other than token) commitment to poverty reduction hardly played a role. Second, they began to use budget support to bring about the desired changes in governance, public finance management and poverty policies.

The fact that the IMF is still the primary entrance condition, maintains the pivotal role of this institution in determining economic policies. This is odd, as most poor countries nowadays do not suffer from short-term macro-economic instability or balance of payments problems. These governments are convinced that low budget deficits and low inflation are important, and they by and large succeeded - at least until the economic crisis of 2008-2009 - in maintaining macro-economic stability. However, this requirement of the budget support donors implies that even countries that do not have balance of payments or debt problems need an IMF agreement. The IMF created the Policy Support Instrument (PSI) to that aim; a regularly monitored IMF program without money.

Looking at the contents of IMF programs, the IMF's Independent Evaluation Office (IEO) concluded that the IMF still includes many structural benchmarks. ${ }^{16}$ In addition, it did not prioritize poverty reduction policies and did not start offering the country alternative policy proposals (IEO, 2007). Some other authors maintain that the IMF has "streamlined" its conditionality, focusing more on issues directly related to fiscal and financial policies (Radelet and Levine, 2008). To the extent this is the case, the World Bank has taken over many of the other structural conditions from the IMF, already in its selection criteria for IDA (see above) but also in the policy dialogue.

Apart from the selection or entrance criteria donors also influence policies and governance in the policy dialogue around budget support. Compared to the conditionality of program aid in the 1990s, more donors now participate in the policy dialogue and conditions have extended to cover all sectors of government policy and government institutions. Donors define concrete policies and targets to be achieved with budget support. In many cases, these policies and targets are defined in a common framework, a Performance Assessment Matrix or Framework, which is negotiated with the government. Officially, the policies and targets are derived from the PRSP or other national plans. But in practice these plans are not sufficiently operational. Donors attempt to micromanage all sectors of government policy, from public finance management via the judiciary to social services and water and sanitation. The extent of national ownership of all these policies and targets can be questioned.

16 The 2010-2013 PSI for Uganda, for example, included a benchmark on the privatization of the pension system. 
In addition, the conditions and procedures of donors within budget support are not fully harmonized. Some donors, in particular the World Bank, define specific actions, "triggers" that must be carried out in order for disbursements to follow. The European Commission defines specific outcomes that must be achieved for part of the money to flow. ${ }^{17}$ Bilateral donors also have specific actions or targets within the joint framework that are more important than others. Most importantly, all donors have different levels of tolerance for different governance issues. Although the governance situation was not very good in most countries, donors tend to respond to deteriorations in governance by suspending the money. As a result, the annual amounts of budget support usually fluctuate a lot. All aid suffers from fluctuations, but low predictability of budget support is more likely to affect macro-economic stability.

Some other expected advantages of budget support did come about (IDD and Associates, 2006). It seems that transaction costs have been reduced, and budget support fully uses local systems. The freely usable money has increased allocative efficiency of spending. In several countries, government budgeting and reporting systems have improved. But usually these improvements in public finance management predate budget support and can also be ascribed to large technical assistance programmes (de Renzio, 2006). There is also evidence that governments have been able to spend more on poverty reduction policies (IDD and Associates, 2006; Komives and Dijkstra, 2006). However, in all cases the quality of this spending is in doubt. There is even some evidence of decreasing efficiency in the social sectors due to abundance of resources and lack of sufficient absorption capacity (Lawson et al., 2005). In general, it is as yet impossible to show that social indicators improved due to budget support. This means that as yet, little is known about the effectiveness of budget support for its ultimate objective, poverty reduction.

The improvements in budgeting processes and in public finance management that were partly induced by budget support usually included increased transparency. Ministries of Finance often publish annual budgets on their websites. In Nicaragua, transparency also improved on actual expenditure, with quarterly reports on actual outturns also posted on the Ministry's website. Civil society used this increased transparency in order to critically monitor the government — at least, until 2007 when a new government took office and transparency was reduced across the board. In Africa, increased transparency on budgets and policies does not always seem to have led to greater domestic accountability. For instance, in Tanzania it was found that civil society or parliaments did not show any interest in government information (Lawson et al., 2005).

\section{Conclusion}

Widespread discontent with the results of aid at the turn of the millennium gave rise to new pleas for more aid and to a new aid approach. This new paradigm was expected to

17 This is the so-called variable tranche, which is determined by the degree of fulfillment of the defined targets. 
increase aid effectiveness through applying more selectivity in the aid allocation, having countries elaborate broadly owned national development strategies focused on poverty reduction, and by promoting donor harmonization and alignment, in particular through fostering the aid modality of budget support.

The paper assessed the theoretical merits of this new aid paradigm as well as the extent of implementation in its first decade and the results. The new aid approach proved to suffer from inherent difficulties. The most important internal contradiction (error of commission) was related to ownership. Ownership is assumed to be the result of selectivity, and is the first principle of both the PRSP and the Paris Declaration. However, it seems that all this is based on the premise that country and donor preferences are the same, in other words, that the country "owns", or is committed to, what the donors want to achieve. If this assumption falls down, conditionality will remain strong and/or harmonization and alignment are logically impossible. In both cases, the new aid paradigm is not likely to improve aid effectiveness.

The errors of omission are at least two-fold. First, the new aid approach does not address the Washington's Consensus failure to bring about economic growth. Second, it does not have a full answer to the economic, institutional and political effects of aid that reduce the absorption capacity. No matter how well harmonized and aligned aid might be, some problems will persist.

Overviewing the implementation of the new aid paradigm, these problems are largely confirmed. The World Bank itself has applied more selectivity in its IDA allocations, on governance and on policies. Other multilateral donors and bilateral donors have not become more selective. Perhaps this is no so bad after all. It is not so clear what the selection criteria for aid allocation decisions should be. Current World Bank practice runs the risk of continued strong conditionality on policies and governance criteria that do not unambiguously enhance growth.

When there are theoretical and practical objections against using selectivity as a means to ensure that donor and recipient preferences concur so that "ownership" is possible, even more pressure will fall on the next element of the new aid paradigm, the PRSP. With 60 countries having presented at least one PRSP, this element of the new aid approach has certainly been implemented. However, governments mostly wrote these strategies in order to get aid and debt relief, and the extent of ownership was usually limited. In addition, donors had far too many objectives with this idea. Even when strategies were owned, they failed in their other assumed functions. PRSPs have not managed to bring about broad consensus in societies on policy priorities and they also failed as operational plans that would guide government activities and expenditure. Donors grossly underestimated the political processes involved in both priority setting and in implementation.

While real ownership of recipient countries is not taken seriously, progress on alignment to country systems and on harmonization is limited. This holds even if we abstract from the increasing appearance of non-DAC donors and of new Global Funds setup by traditional donors that bypass the existing agreements of the Paris 
Declaration. This confirms the problem of the multiple donor preferences and objectives, along with, or instead of, poverty reduction.

After a decade of implementation, about $20 \%$ of aid is provided as non-earmarked resources (budget support). This aid modality is fully aligned with country priorities and systems and usually also to a large extent harmonized. This most likely does not represent an increase over the share of program aid provided in the 1990s. Furthermore, budget support is accompanied by extensive conditionality. Conditions now affect more sectors, and the "policy dialogue" includes many more donors than in the 1990s. In addition, the nature of macro-economic and structural policies has not changed as compared to earlier structural adjustment policies.

What can donors do to improve these practices? Some problems are clearly beyond the competencies of aid agencies. For example, the fact that donors have so many more objectives next to and instead of aid effectiveness, compromising the possibilities to harmonize with other donors and to align with recipient governments, cannot be solved at the level of aid policy makers. This is a political issue within donor countries and although progress is possible, it will be difficult and the process will be slow. It is probably best to accept that a lot of aid money will be wasted in excessive transaction costs, in duplication of efforts and in counterproductive efforts. At the same time, it must also be recognized that some countries do not have the political and institutional absorption capacity for more aid, at least for more aid to governments. Very large amounts of aid weaken domestic capacities and domestic accountability structures, no matter how large the needs are and irrespective of the degree of aid harmonization and alignment.

To the extent that donors care about aid effectiveness and to the extent that the limits of absorption capacity have not been reached yet, there are a few more things that donors can do. First, donors can take recipient ownership much more seriously. But this ownership should not be defined as having country-wide long-term poverty reduction plans, as in the Paris Declaration. Countries should no longer be required to elaborate a PRSP or another long-term, consensus-based development strategy, or to setup sector working groups in which donors can co-decide on sector policies. Justifications for providing aid while respecting sovereignty include compensation for the negative effects of colonialism, of current global economic relations or of climate change (also Whitfield and Fraser, 2009). Donors could begin with accepting the governments' own (election) plans or pamphlets as sources for assessing medium term government intentions. This assessment can lead to a decision whether or not to provide aid. If donors then need operational plans on which to base their (sector) support, they could ask the government to elaborate more short-term term, operational plans for specific themes, sectors or problems. For these plans with a much smaller range, it may be feasible for a government to organize stakeholder consultations and to take different views into account. Donors may offer to facilitate such consultations but should not require a seat on the table. The aim of such consultations is not to foster democracy, but to collect different viewpoints in order to formulate better policies and to further the chances of implementation. 
Second, providing general budget support remains one of the better aid modalities. This aid will be accompanied by a policy dialogue, but donors should avoid overloading it with extensive conditionality. Also in this area, donors would have to respect ownership. Donors cannot possibly know what the right policies and the right governance structures in the recipient country are. Mistakes have been made in the past, and can be expected in the future. This calls for modesty on the donor side. In line with the economic policy rule that the number of targets or goals must be equal to the number of instruments, ${ }^{18}$ this aid instrument should be focused on one target. As general budget support is non-earmarked money that is channelled through the budgeting systems of the recipient country, the policy dialogue around budget support could be targeted to improving the government budgeting and reporting processes. When donors focus the policy dialogue on this target and eliminate the full Christmas tree of other objectives this would also improve the predictability of the money and thus enhance its effectiveness.

\section{References}

Acharya, A, ATFD Lima and M Moore (2006). Proliferation and fragmentation: Transaction costs and the value of aid, Journal of Development Studies, 42(1), 1-21.

Amsden, AH (1989). Asia's Next Giant: South Korea and Late Industrialization. New York/ Oxford: Oxford University Press.

Amsden, AH (2007). Escape from Empire: The Developing World's Journey through Heaven to Hell. Boston: MIT Press.

Andrews, M (2008). Are one-best-way models of effective government suitable for developing countries? Unpublished manuscript.

Arndt, C, S Jones and F Tarp (2014). Assessing foreign aid's long run contribution to growth and development, World Development, 42(1).

Barro, RJ and J Lee (2005). IMF programmes: Who is chosen and what are the effects? Journal of Monetary Economics, 52(7), 1245-1269.

Birdsall, N, S Claessens and I Diwan (2003). Policy selectivity forgone: Debt and donor behaviour in Africa, World Bank Economic Review, 17(3), 409-435.

Booth, D (2003). Introduction and overview to special issue Are PRSPs Making a Difference? The African experience, Development Policy Review, 21(2), 131-159.

Booth, D (2005). Missing Links in the Politics of Development: Learning from the PRSP Experiment, ODI Working Paper No. 256, London: ODI.

Booth, D (2011a). Aid effectiveness: Bringing country ownership (and politics) back in. ODI Working Paper No. 336, London: ODI.

Booth, D (2011b). Aid, institutions and governance: What have we learned? Development Policy Review, 29(S1), S5-S26.

Brautigam, D and S Knack (2004). Foreign aid, institutions and governance in Sub-Saharan Africa, Economic Development and Cultural Change, 52(2), 255-285.

Butkiewicz, JL and H Yanikkaya (2005). The effects of IMF and World Bank Lending on longrun economic growth: An empirical analysis. World Development, 33(3), 371-391.

${ }^{18}$ Already stated by Tinbergen in 1952. 
Canagarajah, S and AV Diesen (2006). The poverty reduction strategy approach six years on: An examination of principles and practice in Uganda. Development Policy Review, 24(6), pp. 647-667.

Chabal, P and JP Daloz (1999). Africa Works: Disorder and Political Instrument. Oxford: James Currey.

Chang (2002). Kicking Away the Ladder: Development Strategy in Historical Perspective, London: Anthem Press.

Chang, H (2007). Bad Samaritans: Rich Nations, Poor Policies and the Threat to the Developing World. London: Random House Business Books.

Cheru, F (2006). Building and supporting PRSPs in Africa: What has worked well so far? What needs changing? Third World Quarterly, 27(2), 355-376.

Cordella, T, LA Ricci and M Ruiz-Arranz (2005). Debt overhang or debt irrelevance? Revisiting the debt-growth link, IMF Working Paper No. 05/223, Washington: IMF.

Cornia, G, R Jolly and F Stewart (Eds.) (1987). Adjustment with a Human Face: Protecting the Vulnerable and Promoting Growth. Oxford: Clarendon Press.

Craig, D and D Porter (2003). Poverty Reduction Strategies: A New Convergence. World Development, 31(1), 53-69.

Depetris Chauvin, N and A Kraay (2006). Who gets Debt Relief?, World Bank Policy Research Working Paper No. 4000. Washington: World Bank.

de Renzio, P (2006). Aid, budgets and accountability: A survey article. Development Policy Review, 24(6), 627-646.

Dijkstra, G (2005). The PRSP approach and the illusion of improved aid effectiveness: Lessons from Bolivia, Honduras and Nicaragua. Development Policy Review, 23(4), 443-464.

Dijkstra, G (2008). The Impact of International Debt Relief. London and New York: Routledge.

Dijkstra, G and K Komives (2011). The PRS approach and the Paris Agenda: Experiences in Bolivia, Honduras and Nicaragua. European Journal of Development Research, 23(2), 191-207.

Dollar, D and V Levin (2006). The increasing selectivity of foreign aid, 1984-2003. World Development, 34(12), 2034-2046.

Driscoll, R and A Evans (2005). Second-generation poverty reduction strategies: New opportunities and emerging issues. Development Policy Review, 23(1), 5-25.

Easterly, W (2005). What did structural adjustment adjust? The association of policies and growth with repeated IMF and world bank adjustment loans. Journal of Development Economics, 76(1), 1-22.

Easterly, W and CR Williamson (2011). Rhetoric versus reality: The best and worst of aid agency practices. World Development, 39(11), 1930-1949.

Fielding, D and F Gibson (2013). Aid and Dutch disease in Sub-Saharan Africa. Journal of African Economies, 22(1), 1-21.

Goldsmith, A (2007). Is governance reform a catalyst for development? Governance, 20, 165-186.

Gottschalk, R (2005). The macro content of PRSPs: Assessing the need for a more flexible macroeconomic policy framework. Development Policy Review, 23(4), 419-442.

Gould, J (Ed.) (2005). The New Conditionality: The Politics of Poverty Reduction Strategies. London and New York: Zed Books.

Grindle, MS (2004). Good enough governance: Poverty reduction and reform in developing countries. Governance: An International Journal of Policy, Administration and Institutions, 17(4), 525-548. 
Guimarães, J and N Avendaño (2007). Pobreza, Problema Postergado, Country Report 2006. Stockholm/The Hague: ISS/SIDA.

Gunsteren, HR van (1976). The Quest for Control: A Critique of the Rational-Central-Rule Approach in Public Affairs. London etc.: John Wiley and Sons.

Hansen, H and F Tarp (2000). Aid effectiveness disputed. Journal of International Development, 12(3), 375-398.

Hansen, H and F Tarp (2001). Aid and growth regressions. Journal of Development Economics, 64(2), 547-570.

Hartog, J (2005). The Participation Conditionality of the PRSP: A Panacea for the Tanzanian Democracy? A Research into the Consequences of the Tanzanian PRSP 1 and NSGRP Participation Processes or the Democracy of Tanzania. MA thesis, Erasmus University Rotterdam.

Hernández, L and SN Katada (1996). Grants and Debt Forgiveness in Africa, World Bank Policy Research Working Paper No. 1653. Washington: The World Bank.

High Level Forum (2005). Paris Declaration on Aid Effectiveness. Paris: OECD-DAC.

Holtom, D (2007). The Challenge of Consensus Building: Tanzania's PRSP 1998-2001. Journal of Modern African Studies, 45(2), 233-251.

Hout, W (2007). The Politics of Aid Selectivity: Good Governance Criteria in World Bank, US and Dutch Development Assistance. London and New York: Routledge.

IDD and Associates (2006). Joint Evaluation of General Budget Support: Synthesis Report. Birmingham, International Development Department, School of Public Policy.

IEO (2004). IEO Evaluation Report on PRSPs and the PRGF. Washington: IMF, Independent Evaluation Office.

IEO (2007). An IEO Evaluation of Structural Conditionality in IMF-supported programmes. Washington: IMF, Independent Evaluation Office.

IOB (2003). Results of International Debt Relief 1990-1999, with case studies of Bolivia, Jamaica, Mozambique, Nicaragua, Uganda, Peru, Tanzania and Zambia (IOB Evaluaties No. 292). Den Haag: Inspectie Ontwikkelingssamenwerking en Beleidsevaluatie.

Kaufmann, D, A Kraay and M Mastruzzi (2004). Governance Matters III: Governance Indicators for 1996-2002. Washington: The World Bank.

Khan, MH (2006). Governance, Economic Growth and Development since the 1960s; Background Paper for World Economic and Social Survey 2006 United Nations.

Khan, MH (2012). Governance and growth: History, ideology and methods of proof. In Noman A, K Botchwey, H Stein and JE Stiglitz (eds.), Good Growth and Governance in Africa: Rethinking Development Strategies, Oxford: Oxford University Press, pp. 51-82.

Killick, T and M Foster (2007). The Macroeconomics of Doubling Aid to Africa. Development Policy Review, 25(2), 167-192.

Knack, S and A Rahman (2004). Donor Fragmentation and Bureaucratic Quality in Aid Recipients, World Bank Policy Research Working Paper No. 3186, Washington: World Bank.

Komives, K, J Aguilar, C Larrea and G Dijkstra (2003). La estrategia Boliviana de reducción de pobreza: ?la nueva brillante idea? (Informe país completo 2003) Evaluación y Monitoreo de las Estrategias de Reducción de la Pobreza en América Latina. Stockholm: SIDA/Institute of Social Studies.

Komives, K., and G. Dijkstra (2006). La responsabilidad de reducir la pobreza, Informe Regional 2006. Stockholm: SIDA-ISS.

Kurtz, MJ and A Schrank (2007). Growth and Governance: Models, Measures, and Mechanisms. The Journal of Politics, 69(2), 538-554. 
Lawson, A, D Booth, M Msuya, S Wangwe and T Williamson (2005). Does General Budget Support Work? Evidence from Tanzania. London: ODI.

Lawson, A, G Boadi, A Ghartey, T Killick and Z Kizilbashl (2007). Joint Evaluation of MultiDonor Budget Support to Ghana: Evaluation of Outputs, Outcomes and Impacts and Recommendations on Future Design and Management of Ghana, MDBS, Oxford.

Lazarus, J (2008). Participation on poverty reduction strategy papers: Reviewing the past, assessing the present and predicting the future. Third World Quarterly, 29(6), 1205-1221.

Lensink, R and H White (1999). Assessing Aid: A Manifesto for Aid for the 21st Century? SIDA Evaluation Report No. 99/17:13, Stockholm: SIDA.

Marchesi, S and A Missale (2004). What Does Motivate Lending and Aid to the HIPCs? Conference Paper: Debt Relief and Global Governance, Rotterdam. Siena/Milano.

Martens, B (2008). Why do Aid Agencies Exist? In W Easterly (ed.). Reinventing Foreign Aid, pp. 285-310, Cambridge Ma/London: MIT Press.

Mekasha, TJ and F Tarp (2013). Aid and growth: What meta-analysis reveals. Journal of Development Studies, 49(4), 564-583.

Molenaers, N and R Renard (2003). The World Bank, participation and PRSP: The bolivian case revisited. European Journal of Development Research, 15(2), 133-161.

Molenaers, N and R Renard (2009). The Trouble with Participation: Assessing the New Aid Paradigm. In M, Kremer, PV Lieshout and R Went (eds.), Doing Good or Doing Better: Development Policies in a Globalising World, pp. 255-278, Amsterdam: Amsterdam University Press.

Mosley, P (1986). Aid effectiveness: The micro-macro paradox. IDS Bulletin, 17(2), 22-27.

Moss, T, G Petterson and Nvd. Walle (2006). An Aid-Institutions Paradox: A Review Essay on Aid Dependency and State Building in Sub-Saharan Africa, CGD Working Paper No. 74, Washington: Center for Global Development.

Moyo, D (2009). Dead Aid: Why Aid is not Working and how there is Another Way for Africa. London/New York: Allan Lane; Penguin Books.

Nabyonga Orem, J, F Ssengooba and S Okuonzi (2009). Can donor aid for health be effective in a poor country? Assessment of prerequisites for aid effectiveness in Uganda. Pan African Medical Journal, 3(9), 1-10.

Nunnenkamp, P and R Thiele (2006). Targeting aid to the needy and deserving: Nothing but promises? The World Economy, 1177-1201.

OECD (2008). Survey on Monitoring the Paris Declaration: Effective Aid by 2010.

OED (2004). The Poverty Reduction Strategy Initiative, an Independent Evaluation of the World Bank's Support through 2003. Washington: World Bank, Operations Evaluation Department.

Przeworski, A and JR Vreeland (2000). The Effect of IMF Programmes on Economic Growth. Journal of Development Economics, 62, 385-421.

Quibria, MG (2014). Aid effectiveness: Research, policy and unresolved issues. Development Studies Research, 1(1), 75-87.

Radelet, S and R Levine (2008). Can we Build a Better Mousetrap? Three New Institutions Designed to Improve Aid Effectiveness. In W Easterly, (ed.). Reinventing Foreign Aid, pp. 431-460, Cambridge Ma/London: MIT Press.

Rajan, RG and A Subramanian (2005). Aid and Growth: What does the Cross-Country Evidence Really Show? Washington: IMF.

Rakner, L, L Mukubvu, N Ngwira, K Smiddy and A Schneider (2004). The Budget as Theatre - The Formal and Informal Institutional Makings of the Budget Process in Malawi. Bergen: Christian Michelsen Institute. 
Renard, R (2005). The Cracks in the New Aid Paradigm. Bonn: EADI Conference.

Rodrik, D (2008). Second Best Institutions. Unpublished manuscript.

Rogerson, A (2005). Aid harmonisation and alignment: Bridging the gaps between reality and the Paris Reform Agenda. Development Policy Review, 23(5), 531-552.

Sachs, J (2005). The End of Poverty: How we can Make it Happen in Our Lifetime. London: Penguin Books.

Serieux, J (2007). Aid and Dutch disease: Nothing to Fear but Fear itself? Poverty in Focus (October), 20-21.

SPA BSWG (2008). Survey of Budget Support 2007 (Final Draft. London: Strategic Partnership with Africa; Budget Support Working Group (SPA BWSG) and ODI.

Stewart, F and M Wang (2003). Do PRSPs Empower Poor Countries and Disempower the World Bank, or is it the Other Way Round?, QEH Working Paper Series No. 108, Oxford: Queen Elizabeth House.

Svensson, J (2008). Absorption Capacity and Disbursement Constraints. In W Easterly, (ed.). Reinventing Foreign Aid, pp. 311-323, Cambridge Ma/London: MIT Press.

Tinbergen, J (1952). On the Theory of Economic Policy. Amsterdam: North Holland.

Van Waeyenberghe, E (2009). Selectivity at Work: Country Policy and Institutional Assessments at the World Bank. European Journal of Development Research, 21(5), 792-810.

Vos, R, M Cabezas and MV Aviles (2003). Reducir la pobreza, se puede experiencias con las estrategias de reducir la pobreza en américa latina. Stockholm: SIDA.

Vreeland, JR (2007). The International Monetary Fund: Politics of Conditional Lending. London and New York: Routledge.

van de Walle, N (2001). African Economies and the Politics of Permanent Crisis, 1979-1999. Cambridge, UK: Cambridge University Press.

White, H (Ed.) (1998). Aid and Macroeconomic Performance: Theory, Evidence and Four Country Cases. Basingstoke/New York: MacMillan/St. Martin's Press.

Whitfield, L (2005). Trustees of Development from Conditionality to Governance: Poverty Reduction Strategy Papers in Ghana. Journal of Modern African Studies, 43(4), 641-664.

Whitfield, L (2009a). Aid and Power: A Comparative Analysis of the Country Studies. In L Whitfield, (ed.), The Politics of Aid: African Strategies for Dealing with Donors, pp. 329 360. Oxford: Oxford University Press.

Whitfield, L (Ed.) (2009b). The Politics of Aid: African Strategies for Dealing with Donors. Oxford: Oxford University Press.

Whitfield, L and A Fraser (2009). Introduction: Aid and Sovereignty. In L Whitfield, (ed.), The Politics of Aid: African Strategies for Dealing with Donors, pp. 1-26, Oxford: Oxford University Press.

Woll, B (2008). Donor harmonisation and government ownership: Multi-donor budget support in Ghana. The European Journal of Development Research, 20(1), 74-87.

World Bank (1998). Assessing Aid: What Works, What Doesn't, and Why. Oxford/New York/ Toronto: Oxford University Press for the World Bank.

World Bank (2005). Economic Growth in the 1990s: Learning from a Decade of Reform. Washington: World Bank.

Wuyts, M (1996). Foreign aid, structural adjustment and public management: The Mozambican experience. Development and Change, 27(4), 717-749. 